\title{
Brand Personality, Strategic Marketing Partnerships and Customer Service Delivery of Public Universities in Kenya
}

\author{
Kegoro Ongoto Henry, \\ Ph.D. Candidate, Department of Business Administration, \\ University of Nairobi, Kenya \\ Prof. Munywoki Justus, \\ Prof. Kibera Francis,
}

Department of Business Administration School of Business,

University of Nairobi, Kenya

Dr. Magutu Peterson,

Department of Management Science School of Business,

University of Nairobi, Kenya

Doi:10.19044/esj.2020.v16n10p238 URL:http://dx.doi.org/10.19044/esj.2020.v16n10p238

\begin{abstract}
The objectives of this study include: to determine the effect of brand personality on customer service delivery of public universities in Kenya and to assess the moderating effect of strategic marketing partnerships on the relationship between brand personality and customer service delivery of public universities in Kenya. The study was underpinned on brand personality model, relationship marketing theory and Service Quality Model (SERVQUAL). Positivistic and cross-sectional research approaches were used. The target population of this study was 84,931 students who were selected from 31 public universities while 61,541 students were selected from a sample frame of 15 public universities. The sample size of 398 respondents was calculated from the sample frame population using Israel formula. Random sampling technique was used to select universities while using multistage purposive sampling method was used to select respondents of the study. Questionnaires were used to collect data. Hypotheses were tested using linear mixed effect (LME) modelling technique fitted with Restricted Maximum Likelihood Estimation (REML) models. The findings of this study revealed existence of a significant influence of brand personality on customer service delivery of public university in Kenya. Further, strategic marketing partnerships was found to have a significant moderating effect on the relationship brand personality and customer service delivery of public
\end{abstract}


university in Kenya. It was recommended that university managers should emphasize on brand personality as well as controlling strategic marketing practices for enhanced customer service delivery.

Keywords: Brand Personality, Strategic Marketing Partnerships and Customer Service Delivery

\section{Introduction}

Unpredictable consumer preferences, influence of globalization and competition, institutions of higher learning are reconsidering on enhancing customer loyalty by embracing brand personality (Giovanni \& Daniela, 2018). Customer service delivery in competitive organizations is viewed to be influenced by brand personality (Gary, José, Susan, Melisaa \& Theresa, 2018). Given the fact that services are heterogeneous in nature and customers have different perceptions on how they are delivered from one institution to another (Banahene, 2017), management of nay organization should rethink on strategic marketing partnership initiatives such as co-branding, co-research and co-distribution for enhance customer experience (Chin, 2016). Nashwan (2015) argues that, to attract and retain customers, organizations should shift from transactional marketing initiatives to more value-adding marketing initiatives such as brand personification and strategic marketing practices. Organizations operating in developing and developed countries can only remain globally competitive by embracing alternative marketing strategies such as brand personality (Chinomona, Masinge \& Sandada, 2014).

Brand personality is considered to be the predominant factor of customer service delivery in any organization (Habibollah \& Zahra, 2013). Brand personality is regarded by Kotler (2010) as a set of human traits attributed to a product, service or organization. Similarly, Keller (2010) describes brand personality as subjective views held by consumers towards services and attributed to human characteristics. Dimensions of brand personality proposed by Aaker (1997) involve: brand sophistication which is regarded as the degree to which a product, service or organization may be perceived to me modern, upper class or technologically advanced. The second dimension is brand competence which is viewed to be the extent to which an organization can have employees with diverse knowledge, experience and skills to serve customers more efficiently and effectively. The third dimension is brand sincerity which is defined as the degree organizations remain truthful or keep customer promises. The fourth dimension is brand excitement which is regarded by Homburg, Kuester and Krohmer (2009) as the level at which organizations delight customers by developing unique products and services that conform with their needs and wants. The fifth dimension which is brand ruggedness is regarded by Doyle and Stern (2010) as the ability of the 
organization to be authoritative and tough as compared to other organizations in the marketplace.

Customer service delivery is viewed to be a function of strategic marketing partnerships (Bhakar, Sher, Shailja \& Shilpa, 2012). Nashwan (2015) opines that, strategic marketing partnership synergies are aimed at accomplishing a specific objective in a more efficient and effective manner. Synonymously, Giovanni and Daniela (2018) describe strategic marketing partnership as an agreement between more than one firm formed with an aim of strategic mutual gain. Firms can agree to partner in co-distribution, cobranding and co-research (Bhakar, et al. 2012). Co-distribution is regarded by Fateh and Boualem (2014) as an arrangement where firms agree to jointly distribute the product or service in the market by sharing intangible or tangible assets. Aaker (1997) argues that co-branding is an agreement between firms where multiple brand names are jointly used to market a single product or service. Co-research is described by Kapferer (2010) as a joint agreement between firms to systematically collect, analyse and interpret data for strategic decision making.

Service delivery is the overall evaluation of service experience by the consumer (Birori, 2014). Given that services are evaluated based on subjective views of customers (Robbins et al., 2010), organizations and more specifically universities should rethink on brand personality as an alternative strategy for global competitiveness. Equally, Kotler (2010) acknowledges that, for any organization to perform effectively in terms of service delivery, embracing a combination of marketing tactics such as strategic marketing and brand reposition will enhance customer loyalty. Service quality dimensions that informs this study as recommended by Parasuraman et al. (1985) involve: reliability, responsiveness, tangibility, assurance and empathy. Service reliability is the degree to which organizations fulfils their promises to customers more efficiently and effectively (Kotler, 2010). Service responsiveness is the degree to which organizations offer services to customers promptly (Jayasundara et al., 2010). Service tangibility is the degree to which customers can associate tangible features to a service. Service assurance is the degree to which workers in an organization can confidently instil trust in customers during service delivery and empathy is the personalized attention provided by organizations to its customers (Kapferer, 2010).

University education is considered to be the driver of economic growth in developed and developing countries. Kenya being one of the developing countries, higher education service sector is considered to be one of the drivers of fulfilling Kenya's Vision 2030 (United Nations Educational, Scientific and Cultural Organization, 2010). Since independence, university education in Kenya has developed tremendously culminating to establishment of many 
public universities. With the increased need for university education by Kenyans, many technical colleges have been transformed into public universities thus increased student enrolment (Inter-University Council for East Africa, 2014). Due to changes of education Acts, 7-4-2-3 education system was replaced by 8-4-4. As result of this changes, Commission for Higher Education (CHE) was replaced by Commission for University Education (CUE) in 2012 to address service quality issues. Quality of services in the 31 public universities existing in Kenya is an issue of concern from various stakeholders such as students, parents and the government (CUE, 2016). With the increased number of student enrolment in public universities in Kenya, production of ill-equipped graduates has been attributed to inability of universities to maintain high standards of education services (Magutu et al., 2010). As a result of this, rethinking on brand personality as an alternative marketing strategy in the university context is inevitable. The motivation of this study was based on the notion that maintenance of quality service standards in the university context in Kenya, would not only result to improved economic stability but also fulfilment of the social pillar of Vision 2030.

\section{Statement of the Problem}

Increased number of student enrolment in public universities, periodical strikes, reduced funding by the government are factors which have compromised the quality of services provided by public universities in Kenya (CUE, 2018). Similarly, Malechwanzi and Mbeke (2016) contend that due to compromised quality of services delivery in public universities, graduates produced annually are ill-equipped to meet the demands of employers. Slow economic growth and high level of unemployment of graduates produced from public universities in Kenya is attributed to compromised quality of services thus the need for universities to rethink on new strategies of improving service quality (Federation of Kenya Employers, 2018). Similarly, Magutu et al. (2010) revealed that inadequate infrastructural facilities in public universities such as lecture halls, hostels and non-competitiveness of academic programs offered by the universities are some of the factors which are attributed to service gaps in public universities. Sanjay (2015) argues that for global competitiveness, organizations should rethink on brand personality in order to exceed customer satisfaction. To attract and retain customers, small and large organizations should use a combination of marketing strategies such as brand personality (Amel, Ayman, Mohamed \& Alaa, 2018). Formation of strategic marketing partnerships is directly associated with improved organizational performance (Raghavan \& Ganesh 2015). Organizations that personify or embrace human qualities in service delivery and compliment it with other factors can attract and retain customers (Matokho \& Anyieni, 2018). 
Despite extensive studies conducted locally, regionally and globally, it is noted that limited studies have investigated the effect of brand personality and strategic marketing partnerships on customer service delivery of public universities in Kenya. For instance, Waithaka (2014) studied the effect of corporate identity management practices, organizational characteristics, corporate image and brand performance of Kenyan universities. A study by Malechwanzi and Mbeke (2016) investigated the effect of policies of access and the quality of higher education in China and Kenya. A study by Owino (2013) sought to investigate the influence of service quality and corporate image on customer satisfaction among university students in Kenya and a study by Mutinda (2016) investigated the influence of brand personality on customer purchase decision of smartphone in selected public university campuses in Nairobi Central Business District, Kenya. Further, a study by Richard, Fiona and John (2017) was conducted in the United Kingdom and established a significant relationship between brand personality and customer loyalty. However, regression method was adopted in data analysis contrary to mixed effect models of this study. Khian et al. (2017) in Malaysia also established a significant relationship between brand personality and brand loyalty but the study was limited to commercial banks contrary to public universities of this study. Studies by Amel et al. (2018) in Egypt and Sanjay (2015) in South Africa sought to examine a direct relationship between variables but failed to examine the moderating effect between variables. Given that these studies examined variables of this study partially and in isolation, focused on different contexts and different methodologies were used to analyse data, their findings were non-generalizable in this study thus formed the basis of investigating the effect of brand personality and strategic marketing partnerships on customer service delivery of public universities in Kenya.

\section{Objectives of the Study}

Objectives developed to guide this study were:

(i) Determine the effect of brand personality on customer service delivery of public universities in Kenya.

(ii) Establish the moderating effect of strategic marketing partnerships on brand personality and customer service delivery of public universities in Kenya.

\section{Research Hypotheses}

Hypotheses formulated to guide this study were:

$\mathrm{H}_{01 \mathrm{a}}$ : Brand personality does not have significant influence on customer service delivery of public universities in Kenya. 
$\mathrm{H}_{01 b}$ : Strategic marketing partnerships does not significantly moderate the relationship between brand personality and customer service delivery of public universities in Kenya.

\section{Theoretical Review}

This section discusses the key theories that informed variables of this study. The theories include: brand personality theory which informs brand personality (independent variable), relationship marketing theory which informs strategic marketing partnerships (moderating variable) and SERVQUAL model which informs customer service quality (dependent variable). Each theory is described below.

This study was informed by brand personality theory founded by Aaker (1997), relationship marketing theory established by Berry (1995) and SERVQUAL model which was founded by Parasuraman, Zeithaml and Berry (1985). The five dimensions of the brand personality theory proposed by Aaker (1997) involve: brand sophistication, brand competence, brand sincerity, brand excitement and brand ruggedness. The theory argues that for any brand to be preferred by customers, it should exhibit the favoured human qualities such as sophistication, competence, sincerity, excitement and ruggedness. Even though the theory has been applied in social studies (Mutinda, 2016, Isaid \& Faisal, 2015, Charraz et al. 2014), universality and operationalization of its constructs from one context to another is still questionable thus the need of retesting it in this study on the premise that universities can improve customer service delivery embracing brand personality and the same time complimented with strategic marketing partnerships.

Relationship marketing theory argues that, creation of functional partnerships not only enhance stakeholder value in organizations but also enhance customer loyalty (Doyle \& Stern, 2010). The theory advocated for joint production of goods, branding, distribution and research can result to enhanced customer service delivery. Despite constraints of operationalizing concepts of this theory from one context to another (Kulecho \& Anyieni, 2018), it was retested in this study based on the notion that universities can enhance customer service delivery by embracing strategic marketing partnerships such as co-distribution, co-branding and co-research. Furthermore, the dependent variable of this study was anchored on SERVQUAL model which was founded by Parasuraman, Zeithaml and Berry (1985). The theory was retested in this study based on the assumption that customer service delivery in the university context can be measured based on five tenets which include: reliability, responsiveness, assurance, empathy and tangibles. 


\section{Review of Related Literature}

This section discusses key variables of the study in relation to existing empirical studies conducted globally, regionally and locally. Further, research gaps are identified as well as ways of addressing the research gaps are discussed.

\section{Brand Personality and Customer Service Delivery}

Sohini, Rejoice, Norman and Eugine (2019) revealed a positive relationship between brand equity and rebranding among small enterprises in the UK. However, it was noted that the study analysed data using a single approach contrary to multi-level approach of this study. It was revealed by Abdulsattar (2019) that brand personality had a significant impact on user imagery, advertisement style and logo but failed to examine the relationship between brand personality and customer service delivery in the university context. Further, the study was limited to tangible products contrary to pure services offered in the university context. In a comparative study conducted by Ewa and Wawrzyniec (2019), it was revealed that there exist differences between brand personality and customer perceived value. Brand sophistication can positively influence customer service delivery (Matti et al., 2015). Similarly, Chin (2016) acknowledges that customer perceived value is influenced by brand personality. Experience and unique personalities of service providers can positively influence customer loyalty and vice versa (Bijuna et al., 2016). Organizations that promptly fulfils customer promises can attract and retain customers (Charraz and Muhammad (2014). Whilst, Nashwan (2015) contends that customer satisfaction in influenced by brand that are perceived to be valuable and conform with customer expectations after consumption.

Thongthip and Polyorat (2015) in Sweden hold that, despite variation of brand personality dimensions on brand performance, organizations have to apply brand personality in order to survive. Organizational performance is a function of brand personality (Chinomona, Masinge \& Sandada, 2014). Mutinda (2016) noted that brand personality had a significant impact on customer purchase intentions of smart phones. However, the study was limited to tangible products but not pure services. Malechwanzi and Mbeke (2016) identified that brand ruggedness was perceived to be the ability of organization to be authoritative and tough. Brand personality was found to be insignificant and at the same time significant on perceived service quality. Based on the fact that services are heterogeneous, brand personality is viewed to be one of the marketing strategies that can influence customer loyalty (Teimouri, Fanae, Jenab, Khoury \& Moslehpour, 2016). This study addressed the knowledge gaps by focusing by examining the moderating effect of strategic marketing partnerships on the relationship between brand personality and customer 
service delivery in the university context. Despite the fact that Soni (2015) found out that brand equity was influenced by service quality, it was noted that the study partially examined variables of this study. Positive student perception towards the brand is viewed to be influenced by brand personality (Eldegwy, Elsharnouby \& Kortam, 2018).

Eldegwy et al. (2018) in Egypt identified that modernization of education services, improvement of infrastructural facilities and modernization of library services can create a positive impact on brand performance. Nevertheless, it was noted that structural equation modelling was used in data analysis contrary mixed effect models adopted by this study. Hsu (2014) and Sun et al. (2014) also revealed that, not all brand personality can be used to measure service quality. Since personality is a multidimensional construct, it is difficulty to assume that all the dimensions can influence service quality. Despite extensive related studies which have been conducted on the link between brand personality and customer service delivery (Hong \& Ha, 2016, Pradhan et al., 2016 \& Tho et al., 2016), operationalizing constructs of brand personality model is attributed to constraints from one context to another (Willems \& Swinnen, 2011).

\section{Brand Personality, Strategic Marketing Partnerships and Customer Service Delivery}

Customer service delivery is considered to be influenced by brand personality and strategic marketing partnerships. Kulecho and Anyieni (2018) hold that strategic partnerships can have a significant impact on organizational performance. The study concluded that firms that jointly market products and conduct product research can easily attract and retain customers. However, it was noted that indicators used to measure strategic partnerships were different from that of this study. Sustainable customer relationship is considered to be a function of strategic partnerships (Fateh \& Boualem, 2014). Giovanni and Daniela (2018) opine that despite the fact that strategic partnerships are considered to have a significant impact on organizational performance, to some extent, partnerships formed may fail to work due to lack of trust and confidence among partners. Ability of organizations to share strategic resources such as information, technology and employee knowledge can have a significant impact on customer service delivery (Owino et al., 2014).

Subsequently, Bhakar, Sher, Shailja and Shilpa (2012) found out that there exist differences between strategic marketing partnerships and performance of firms in India. Though, it was observed that the study was conducted in India which is a different context culturally and geographically and its findings are non-generalizable in this study. Mohamud et al. (2015) on the other had found out that strategic marketing partnerships can enhance customer satisfactions if effectively embraced. Equally, Khian et al. (2017) 
emphasize that co-production and marketing of products can give organizations a competitive edge in attracting and retaining customers. Even though studies have been conducted to examine the link between strategic marketing partnerships on customer service delivery (Bhakar,2012), it is observed that there are limited studies conducted to investigate the relationship between brand personality and strategic marketing partnerships on customer service delivery in the university context. Most of the studies conducted are inclined towards strategic management discipline (Matata \& Oduor, 2014), but not marketing discipline. Matata and Oduor (2014) concluded that, for enhanced customer loyalty, strategic marketing partnerships can facilitate development of new products and contribute to reduced marketing and production costs. For organizations to be globally competitive in terms of service delivery, strategic marketing partnership is key (Matokho \& Anyieni, 2018).

\section{Conceptual Framework Guiding the Study}

Figure 2.1 represents the interrelationship of the study variables. The independent variable of the study (brand personality) is measured using five metrics which involve: brand sophistication, competence, sincerity, excitement and ruggedness. The dependent variable (customer service delivery) is measured using five metrics which involve: reliability, responsiveness, assurance, empathy and tangibles. The moderating variable (strategic marketing partnerships) considered to moderate the relationship between brand personality and customer service delivery is measured using indicators such as co-distribution, co-branding, co-research.

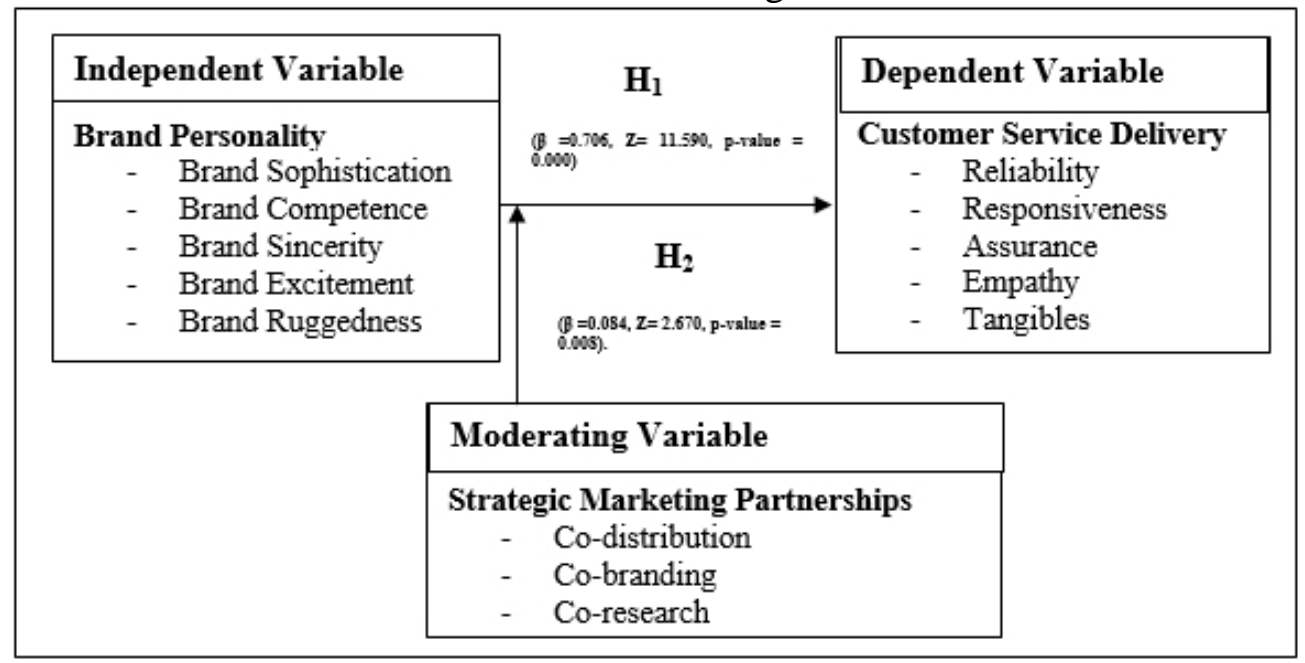

Figure 2.1: Conceptual Framework

Source: Researcher's Demonstration 


\section{Methodology}

Positivist approach and cross-sectional research design were adopted in this study. The target population of this study was 84,931 students who were selected from 31 public universities while 61,541 students were selected from sample frame of 15 public universities. The sample size of 398 respondents was calculated from the sample frame population using Israel formula (2009). Random sampling technique was used to select universities while multistage purposive sampling method was used to select respondents of the study. Primary data was collected using self-developed questionnaires with open and closed ended questions. The questionnaire was divided into four section, A, D. Section A, captured demographic data of fourth year undergraduate students in public universities. Section B, captured data on brand personality variable adaptted from brand personality scale developed by Aaker (1997). These are: brand sophistication, competence, sincerity, excitement and ruggedness. Section C, captured data on strategic marketing partnerships variable adapted from relationship marketing theory developed by Doyle and Stern (2010).

The selected indicators used to measure strategic marketing partnerships variable are: co-distribution, co-branding, co-research and Section D, captured data on customer service delivery variable adapted from SERVQUAL model founded by Parasuraman, Zeithaml and Berry (1985). Indicators used to measure this variable are: reliability, responsiveness, assurance, empathy and tangibles. Items on the questionnaire were measured using a Likert-type scale of measurement $(5=$ strongly agree to $1=$ strongly disagree). Reliability of the research instrument was ascertained by Cronbach Alpha test. Cronbach Alpha values above 0.7 were used to confirm internal consistency of the research instruments as recommended by Byrne (2017). Confirmatory Factor Analysis (CFA) and Average Variance Extracted (AVE) technique were used to confirm convergent validity of the variables as recommended by Byrne (2017). The linear mixed effect (LME) modelling technique as used in testing the hypothesis of the study.

\section{Results}

Out of the 398 questionnaires administered, only 314 questionnaires were retuned fully filled. This number of questionnaires returned was translated to $79.889 \%$ response rate which is above $60 \%$ threshold as recommended by Byrne (2017).

\section{Findings of the Study}

For basic description of data, descriptive statistics was used to analyse data. Considering the fact that multi-level approach was used to analyse data, overall mean scores were used to ascertain the mixed effect of brand 
personality within students in a university and as well as between universities. Further, mean scores, standard deviations and coefficient of variations were used to describe student views concerning brand personality on service delivery within and between public universities in Kenya. The findings are presented as shown in Table 1, 2 and 3.

\section{Descriptive Statistics for Brand Personality}

Brand personality dimensions which include: brand sophistication, brand competence, brand sincerity brand excitement and brand ruggedness were operationalized using the following statements as it was reflected in the research instrument as shown in Table 1.

Table 1: Brand Personality Dimensions

\begin{tabular}{|c|c|c|c|c|c|}
\hline Variable & & Mean & Std. Dev. & C.V. & Observations \\
\hline \multicolumn{6}{|l|}{ Brand Sophistication Statements } \\
\hline \multirow{3}{*}{$\begin{array}{l}\text { My university has a reliable internet that } \\
\text { is accessible by all students within its } \\
\text { vicinity }\end{array}$} & Overall & 3.277 & 1.187 & $36.2 \%$ & $\mathrm{~N}=314$ \\
\hline & Between & & 0.517 & $15.8 \%$ & $\mathrm{n}=12$ \\
\hline & Within & & 1.086 & $33.2 \%$ & $\mathrm{~T}-\mathrm{bar}=26.1667$ \\
\hline \multirow{3}{*}{$\begin{array}{l}\text { Lecturers in my university always use } \\
\text { ICT tools such as laptops and projectors } \\
\text { to facilitate lectures }\end{array}$} & Overall & 3.704 & 1.057 & $28.5 \%$ & $\mathrm{~N}=314$ \\
\hline & Between & & 0.260 & $7.0 \%$ & $\mathrm{n}=12$ \\
\hline & Within & & 1.024 & $27.6 \%$ & T-bar $=26.1667$ \\
\hline \multirow{3}{*}{$\begin{array}{l}\text { My university has a biometric system of } \\
\text { monitoring student class attendance }\end{array}$} & Overall & 2.191 & 1.309 & $59.8 \%$ & $\mathrm{~N}=314$ \\
\hline & Between & & 0.525 & $23.9 \%$ & $\mathrm{n}=12$ \\
\hline & Within & & 1.214 & $55.4 \%$ & $\mathrm{~T}-\mathrm{bar}=26.1667$ \\
\hline \multicolumn{6}{|l|}{ Brand Competence Statements } \\
\hline \multirow{3}{*}{$\begin{array}{l}\text { My lecturers use a combination of } \\
\text { methods to evaluate students such as; } \\
\text { sit-in continuous assessment tests, } \\
\text { individual and group assignments }\end{array}$} & Overall & 4.274 & 0.873 & $20.4 \%$ & $\mathrm{~N}=314$ \\
\hline & Between & & 0.206 & $4.8 \%$ & $\mathrm{n}=12$ \\
\hline & Within & & 0.850 & $19.9 \%$ & $\mathrm{~T}$-bar $=26.1667$ \\
\hline \multirow{3}{*}{$\begin{array}{l}\text { Lecturers in university have high level } \\
\text { of professionalism }\end{array}$} & Overall & 3.866 & 0.926 & $24.0 \%$ & $\mathrm{~N}=314$ \\
\hline & Between & & 0.322 & $8.3 \%$ & $\mathrm{n}=12$ \\
\hline & Within & & 0.873 & $22.6 \%$ & T-bar $=26.1667$ \\
\hline \multirow{3}{*}{$\begin{array}{l}\text { The non-teaching staff in my university } \\
\text { offer excellent services to students }\end{array}$} & Overall & 3.646 & 1.084 & $29.7 \%$ & $\mathrm{~N}=314$ \\
\hline & Between & & 0.298 & $8.2 \%$ & $\mathrm{n}=12$ \\
\hline & Within & & 1.035 & $28.4 \%$ & T-bar $=26.1667$ \\
\hline \multicolumn{6}{|l|}{ Brand Sincerity Statements } \\
\hline \multirow{3}{*}{$\begin{array}{l}\text { Information provided by the teaching } \\
\text { staff in my university is reliable }\end{array}$} & Overall & 3.723 & 0.974 & $26.2 \%$ & $\mathrm{~N}=314$ \\
\hline & Between & & 0.237 & $6.4 \%$ & $\mathrm{n}=12$ \\
\hline & Within & & 0.945 & $25.4 \%$ & T-bar $=26.1667$ \\
\hline \multirow{3}{*}{$\begin{array}{l}\text { Services offered by my university } \\
\text { always exceed my expectations }\end{array}$} & Overall & 3.025 & 1.099 & $36.3 \%$ & $\mathrm{~N}=314$ \\
\hline & Between & & 0.395 & $13.1 \%$ & $\mathrm{n}=12$ \\
\hline & Within & & 1.034 & $34.2 \%$ & T-bar $=26.1667$ \\
\hline
\end{tabular}




\begin{tabular}{|c|c|c|c|c|c|}
\hline \multirow{3}{*}{$\begin{array}{l}\text { I always make enquiries about my fee } \\
\text { balance, book a room and print } \\
\text { provisional transcripts without } \\
\text { difficulties }\end{array}$} & Overall & 3.513 & 1.210 & $34.5 \%$ & $\mathrm{~N}=314$ \\
\hline & Between & & 0.338 & $9.6 \%$ & $\mathrm{n}=12$ \\
\hline & Within & & 1.172 & $33.4 \%$ & T-bar $=26.1667$ \\
\hline \multicolumn{6}{|l|}{ Brand Excitement Statements } \\
\hline \multirow{3}{*}{$\begin{array}{l}\text { My lecturers are always punctual in } \\
\text { class }\end{array}$} & Overall & 3.322 & 1.079 & $32.5 \%$ & $\mathrm{~N}=314$ \\
\hline & Between & & 0.248 & $7.5 \%$ & $\mathrm{n}=12$ \\
\hline & Within & & 1.052 & $31.7 \%$ & T-bar $=26.1667$ \\
\hline \multirow{3}{*}{$\begin{array}{l}\text { Sports activities and student clubs are } \\
\text { supported by the university }\end{array}$} & Overall & 3.490 & 1.145 & $32.8 \%$ & $\mathrm{~N}=314$ \\
\hline & Between & & 0.214 & $6.1 \%$ & $\mathrm{n}=12$ \\
\hline & Within & & 1.127 & $32.3 \%$ & T-bar $=26.1667$ \\
\hline \multirow{3}{*}{$\begin{array}{l}\text { I am always satisfied with the teaching } \\
\text { methodologies used by my lecturers }\end{array}$} & Overall & 3.557 & 1.060 & $29.8 \%$ & $\mathrm{~N}=314$ \\
\hline & Between & & 0.301 & $8.5 \%$ & $\mathrm{n}=12$ \\
\hline & Within & & 1.019 & $28.6 \%$ & T-bar $=26.1667$ \\
\hline \multirow{3}{*}{$\begin{array}{l}\text { My university has student } \\
\text { entertainment center }\end{array}$} & Overall & 3.127 & 1.327 & $42.4 \%$ & $\mathrm{~N}=314$ \\
\hline & Between & & 0.563 & $18.0 \%$ & $\mathrm{n}=12$ \\
\hline & Within & & 1.214 & $38.8 \%$ & T-bar $=26.1667$ \\
\hline \multicolumn{6}{|l|}{ Brand Ruggedness Statements } \\
\hline \multirow{3}{*}{$\begin{array}{l}\text { My university has degree programs that } \\
\text { attract brilliant students }\end{array}$} & Overall & 3.946 & 1.055 & $26.7 \%$ & $\mathrm{~N}=314$ \\
\hline & Between & & 0.404 & $10.2 \%$ & $\mathrm{n}=12$ \\
\hline & Within & & 0.988 & $25.0 \%$ & T-bar $=26.1667$ \\
\hline \multirow{3}{*}{$\begin{array}{l}\text { My university has unique courses that } \\
\text { attract both local and international } \\
\text { students }\end{array}$} & Overall & 3.710 & 1.100 & $29.6 \%$ & $\mathrm{~N}=314$ \\
\hline & Between & & 0.489 & $13.2 \%$ & $\mathrm{n}=12$ \\
\hline & Within & & 1.009 & $27.2 \%$ & $\mathrm{~T}-\mathrm{bar}=26.1667$ \\
\hline \multirow{3}{*}{$\begin{array}{l}\text { The environment in which my } \\
\text { university is located is conducive for } \\
\text { learning }\end{array}$} & Overall & 3.981 & 1.069 & $26.9 \%$ & $\mathrm{~N}=314$ \\
\hline & Between & & 0.418 & $10.5 \%$ & $\mathrm{n}=12$ \\
\hline & Within & & 0.985 & $24.7 \%$ & T-bar $=26.1667$ \\
\hline
\end{tabular}

Source: Primary Data

As shown in Table 1, the overall mean scores for all the statements that were used to measure brand personality dimensions were above 3.00, while the mean scores of students within the universities were slightly higher as compared to the mean scores of students between the universities. However, the overall mean score for 1 statement out the 16 statements of brand personality dimensions is below 2.00. The variations in findings indicate that most of the students within the universities generally agreed that brand personality had a significant influence on customer service delivery as compared to views held by students between the universities. Despite these findings, it was also revealed by a few students within and between the public universities that, to some extent brand personality was not embraced based on 
the fact that biometric systems to monitor student class attendance were nonexistent.

\section{Descriptive Statistics for Strategic Marketing Partnerships Dimensions}

Strategic marketing partnership dimensions which include: codistribution, co-distribution and co-research were operationalized using the following statements as it was reflected in the research instrument as shown in Table 2.

Table 2: Strategic Marketing Partnership Dimensions

\begin{tabular}{|c|c|c|c|c|c|}
\hline \multicolumn{2}{|l|}{ Co-Distribution Statements } & Mean & \multirow{2}{*}{$\begin{array}{c}\text { Std. Dev. } \\
1.264\end{array}$} & \multirow{2}{*}{$\begin{array}{l}\text { C.V. } \\
39.2 \%\end{array}$} & Observations \\
\hline I am encouraged to apply for & Overall & 3.223 & & & $\mathrm{~N}=314$ \\
\hline postgraduate scholarships offered by & Between & & 0.545 & $16.9 \%$ & $\mathrm{n}=12$ \\
\hline $\begin{array}{l}\text { international universities after } \\
\text { graduating }\end{array}$ & Within & & 1.158 & $35.9 \%$ & $\mathrm{~T}-\mathrm{bar}=26.1667$ \\
\hline I am a member of inter-university & Overall & 2.720 & 1.422 & $52.3 \%$ & $\mathrm{~N}=314$ \\
\hline clubs & Between & & 0.679 & $25.0 \%$ & $\mathrm{n}=12$ \\
\hline & Within & & 1.264 & $46.5 \%$ & $\mathrm{~T}-\mathrm{bar}=26.1667$ \\
\hline \multicolumn{6}{|l|}{ Co-Branding Statements } \\
\hline I am attracted by international student & Overall & 3.019 & 1.228 & $40.7 \%$ & $\mathrm{~N}=314$ \\
\hline clubs & Between & & 0.352 & $11.6 \%$ & $\mathrm{n}=12$ \\
\hline & Within & & 1.182 & $39.1 \%$ & T-bar $=26.1667$ \\
\hline I am pleased by events sponsored by & Overall & 3.089 & 1.196 & $38.7 \%$ & $\mathrm{~N}=314$ \\
\hline affiliate international universities & Between & & 0.381 & $12.3 \%$ & $\mathrm{n}=12$ \\
\hline & Within & & 1.143 & $37.0 \%$ & T-bar $=26.1667$ \\
\hline \multicolumn{6}{|l|}{ Co-Research Statements } \\
\hline \multirow{3}{*}{$\begin{array}{l}\text { My university considers student } \\
\text { exchange programs to be the source of } \\
\text { new knowledge }\end{array}$} & Overall & 3.605 & 1.089 & $30.2 \%$ & $\mathrm{~N}=314$ \\
\hline & Between & & 0.352 & $9.8 \%$ & $\mathrm{n}=12$ \\
\hline & Within & & 1.039 & $28.8 \%$ & $\mathrm{~T}-\mathrm{bar}=26.1667$ \\
\hline My university has an open access inter- & Overall & 2.879 & 1.261 & $43.8 \%$ & $\mathrm{~N}=314$ \\
\hline university platform where students & Between & & 0.349 & $12.1 \%$ & $\mathrm{n}=12$ \\
\hline exchange academic ideas & Within & & 1.219 & $42.3 \%$ & $\mathrm{~T}-\mathrm{bar}=26.1667$ \\
\hline
\end{tabular}

\section{Source: Primary Data}

As shown in Table 2, the overall mean scores for all the 5 statements that were used to measure strategic marketing partnership dimensions were above 3.00, while the mean scores of students within the universities were slightly higher as compared to the mean scores of students between the universities. However, the overall mean score for 2 statements out the 8 statements of strategic marketing partnership dimensions is below 2.00. The variations in findings indicate that most of the students within the universities generally agreed that strategic marketing partnership had a significant influence on customer service delivery as compared to views held by students between the universities. Despite these findings, it was also revealed by some students within and between the public universities that, to some extent 
strategic marketing partnership was not embraced based on the fact that students were not members of inter-university clubs.

\section{Descriptive Statistics for Customer Service Delivery}

Customer service delivery dimensions which include: reliability, responsiveness, assurance, empathy and tangibles were consolidated and operationalized using the following statements as it was reflected in the research instrument as shown in Table 3.

Table 3: customer service Delivery Dimensions

\begin{tabular}{|c|c|c|c|c|c|}
\hline Variable & & Mean & Std. Dev. & C.V. & Observations \\
\hline \multirow{3}{*}{$\begin{array}{l}\text { I receive prompt services in my } \\
\text { university }\end{array}$} & Overall & 3.494 & 0.993 & $28.4 \%$ & $\mathrm{~N}=314$ \\
\hline & Between & & 0.318 & $9.1 \%$ & $\mathrm{n}=12$ \\
\hline & Within & & 0.945 & $27.0 \%$ & $\mathrm{~T}-\mathrm{bar}=26.1667$ \\
\hline \multirow{3}{*}{$\begin{array}{l}\text { I am always given personalized } \\
\text { attention by my lecturers }\end{array}$} & Overall & 3.150 & 1.051 & $33.4 \%$ & $\mathrm{~N}=314$ \\
\hline & Between & & 0.399 & $12.7 \%$ & $\mathrm{n}=12$ \\
\hline & Within & & 0.979 & $31.1 \%$ & T-bar $=26.1667$ \\
\hline \multirow{3}{*}{$\begin{array}{l}\text { I access my results through student } \\
\text { portal at the right time }\end{array}$} & Overall & 3.290 & 1.348 & $41.0 \%$ & $\mathrm{~N}=314$ \\
\hline & Between & & 0.627 & $19.1 \%$ & $\mathrm{n}=12$ \\
\hline & Within & & 1.207 & $36.7 \%$ & T-bar $=26.1667$ \\
\hline \multirow{3}{*}{$\begin{array}{l}\text { My university always responds } \\
\text { appropriately to student grievances }\end{array}$} & Overall & 3.010 & 1.192 & $39.6 \%$ & $\mathrm{~N}=314$ \\
\hline & Between & & 0.515 & $17.1 \%$ & $\mathrm{n}=12$ \\
\hline & Within & & 1.091 & $36.2 \%$ & $\mathrm{~T}-\mathrm{bar}=26.1667$ \\
\hline \multirow{3}{*}{$\begin{array}{l}\text { I can recommend this university to } \\
\text { other students }\end{array}$} & Overall & 3.841 & 1.145 & $29.8 \%$ & $\mathrm{~N}=314$ \\
\hline & Between & & 0.335 & $8.7 \%$ & $\mathrm{n}=12$ \\
\hline & Within & & 1.099 & $28.6 \%$ & $\mathrm{~T}-\mathrm{bar}=26.1667$ \\
\hline \multirow{3}{*}{$\begin{array}{l}\text { I am willing to pursue my } \\
\text { postgraduate studies in this } \\
\text { university }\end{array}$} & Overall & 3.299 & 1.340 & $40.6 \%$ & $\mathrm{~N}=314$ \\
\hline & Between & & 0.527 & $16.0 \%$ & $\mathrm{n}=12$ \\
\hline & Within & & 1.239 & $38.6 \%$ & $\mathrm{~T}-\mathrm{bar}=26.1667$ \\
\hline \multirow{3}{*}{$\begin{array}{l}\text { Fulfilment of promises is a priority } \\
\text { by the teaching and non-teaching } \\
\text { staff }\end{array}$} & Overall & 3.070 & 1.073 & $35.0 \%$ & $\mathrm{~N}=314$ \\
\hline & Between & & 0.316 & $10.3 \%$ & $\mathrm{n}=12$ \\
\hline & Within & & 1.032 & $33.6 \%$ & $\mathrm{~T}-\mathrm{bar}=26.1667$ \\
\hline \multirow{3}{*}{$\begin{array}{l}\text { Fulfilment of promises is a priority } \\
\text { by the teaching staff }\end{array}$} & Overall & 3.258 & 1.076 & $33.0 \%$ & $\mathrm{~N}=314$ \\
\hline & Between & & 0.244 & $7.5 \%$ & $\mathrm{n}=12$ \\
\hline & Within & & 1.051 & $32.3 \%$ & T-bar $=26.1667$ \\
\hline
\end{tabular}

Source: Primary Data

As shown in Table 3, the overall mean scores for all the 8 statements that were used to measure customer service delivery dimensions were above 3.00 , while the mean scores of students within the universities were slightly higher as compared to the mean scores of students between the universities. The variations in findings indicate that most of the students within the universities generally agreed that customer service delivery was measured in terms of promptness of services, personalized attention, timely access of exam results, timely response to grievances, recommendation the university to other 
students, willingness of students to pursue postgraduate studies in the same university, prompt fulfilment of promises by teaching and non-teaching staff.

\section{Test of Hypotheses}

\section{Hypothesis One}

$\mathrm{H}_{01 \mathrm{a}}$ : Brand personality does not have significant influence on customer service delivery of public universities in Kenya.

$\mathrm{H}_{1 \mathrm{a}}$ : Brand personality has significant influence of on customer service delivery of public universities in Kenya.

Using Restricted Maximum Likelihood Estimation (REML) to test this hypotheses, the model below was adopted to test the interaction effect of brand personality on customer service delivery of public universities in Kenya.

$Y_{i j}=0+0.706 \mathrm{X}_{i j}+\varepsilon_{i j}$

$\alpha_{0}=0.033 \alpha_{0 j}+0.026 X_{0 j}+\mu_{j}$

Where;

$Y_{i j}$ is the level of customer service delivery as perceived by student $\mathrm{i}$ for university $\mathrm{j}$

$X_{i j}$ is the level of brand personality as perceived by student $\mathrm{i}$ for university $\mathrm{j}$ (level-1)

$\gamma_{0}$ is the level 2 intercept equation of customer service deliver across the universities

$X_{0 j}$ is the level of brand personality of university $\mathrm{j}$ (level-2)

$\mu_{1 \mathrm{j}}$ is the random error at level-2

$\varepsilon_{i j}$ is the overall error margin

The results of the analysis are illustrated as summarized in Table 1 below:

Table 4: Mixed Effects of Brand Personality on Customer Service Delivery

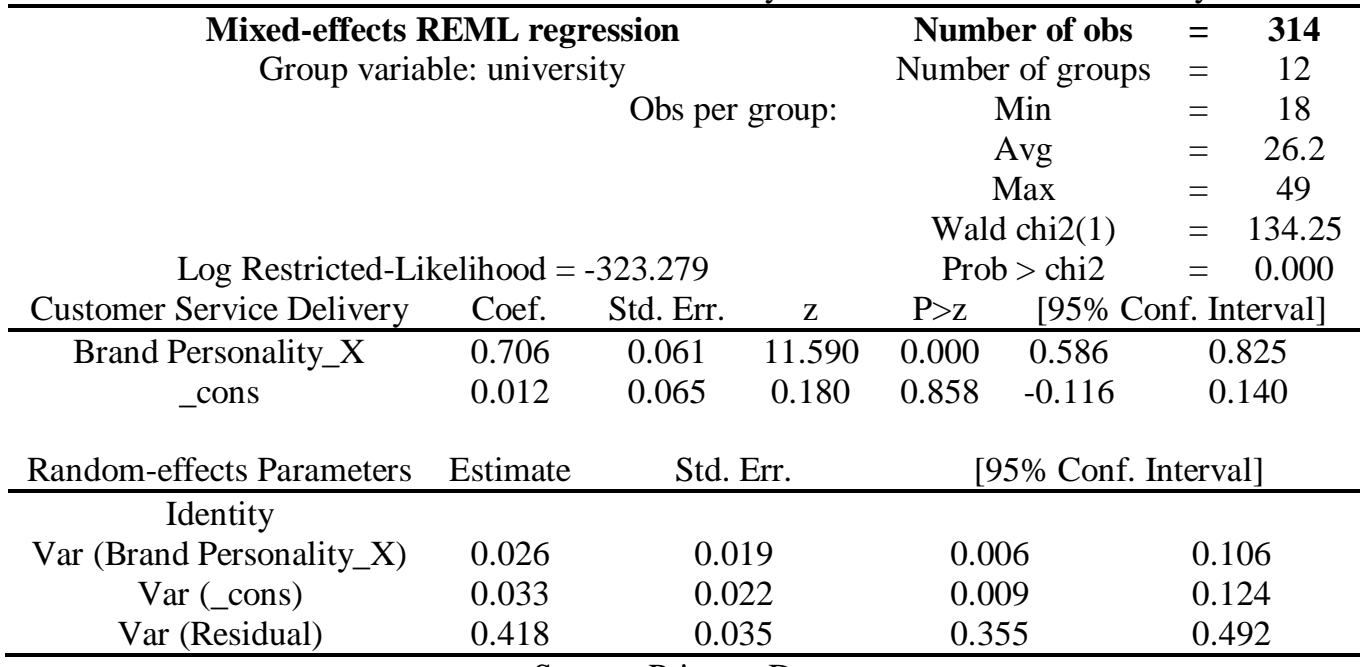


As shown in Table 4, the results of Restricted Maximum Likelihood Estimation (REML) of the hypothesized effect between brand personality and customer service delivery of public universities indicate a fixed significant effect between brand personality and customer service delivery with the model summary showing (chi-square $=134.25, \mathrm{p}$-value $=0.000)$. At level-1 (perception of brand personality within university students), brand personality coefficient estimate is significant $(\beta=0.706, Z=11.590$, $p$-value $=0.000)$ while at level-2 (perception of brand personality between university students) was also found to be significant at random intercept and the random slope. The random effect of brand personality on customer service delivery between universities was significant $(\mathrm{ICC}=7.2 \%, \mathrm{LR}=13.54$, $\mathrm{p}$-value $=0.0011$ )

In relation to the foregoing findings, the null hypothesis $\left[\mathrm{H}_{01 \mathrm{a}}\right]$ which states that "Brand personality does not have significant influence on customer service delivery of public universities in Kenya" would be rejected while the alternative hypothesis $\left[\mathrm{H}_{1 \mathrm{a}}\right]$ would be accepted.

\section{Hypothesis Two}

$\mathrm{H}_{01 \mathrm{~b}}$ : Strategic marketing partnerships does not significantly moderate the relationship between brand personality and customer service delivery of public universities in Kenya.

$\mathrm{H}_{1 \mathrm{~b}}$ : Strategic marketing partnerships significantly moderates the relationship between brand personality and customer service delivery of public universities in Kenya.

Using Restricted Maximum Likelihood Estimation (REML) to test this hypothesis, the model below was adopted to test the moderating effect of strategic marketing partnerships on the relationship between brand personality and customer service delivery of public universities in Kenya.

$Y_{i j}=\gamma_{0}+0.609 \mathrm{X}_{i j}+0.180 \mathrm{Z}_{1, i j}+0.084 \mathrm{X \# Z} Z_{1, i j}+\varepsilon_{i j}$

$\gamma_{0}=0.040 \alpha_{0 j}+0.013 X_{0 j}+\mu_{j}$

Where;

$Y_{i j}$ is the level of customer service delivery as perceived by student $\mathrm{i}$ for university $\mathrm{j}$

$X_{i j}$ is the level of brand personality as perceived by student $\mathrm{i}$ for university $\mathrm{j}$ (level-1)

$Z_{1, i j}$ is the level of strategic marketing partnership as perceived by student $\mathrm{i}$ for university $\mathrm{j}$ (level-1)

$X \# Z_{1, i j}$ is the interaction between brand personality and strategic marketing partnership at level-1

$\gamma_{0}$ is the level 2 intercept equation of customer service deliver across the universities

$X_{0 j}$ is the level of brand personality of university $\mathrm{j}$ (level-2) 
$\mu_{1 \mathrm{j}}$ is the random error at level-2

$\varepsilon_{i j}$ is the overall error margin

The results of the analysis are illustrated as summarized in Table 2 below:

Table 5: Random Moderating Effect of Strategic Marketing Partnerships on the Relationship between Brand Personality and Customer Service Delivery

Mixed-effects REML regression

Group variable: university

Log restricted-likelihood $=-309.096$

$\begin{array}{ccc}\text { Number of obs } & = & 314 \\ \text { Number of groups } & = & 12 \\ \text { Min } & = & 18 \\ \text { Avg } & = & 26.2 \\ \text { Max } & = & 49 \\ \text { Wald chi2 }(1) & = & 218.20 \\ \text { Prob }>\text { chi2 } & = & 0.000\end{array}$

Customer Service Delivery

Brand personality, X
Strategic Marketing Partnersh
X\#Z1
_cons
Random-effects Parameters

Identity

Var (Brand personality_X)

Var (_cons)

Var (Residual)
Coef. Std. Err.

0.609

0.059

0.180

0.049

0.032

0.084

0.071

$-0.025$

Estimate Std. Err.

10.300
3.690
2.670
-0.350

$\mathbf{P}>\mathbf{z}$

[95\% Conf. Interval]

$\begin{array}{lll}0.000 & 0.493 & 0.725\end{array}$

$0.000 \quad 0.085$

0.276

$0.008 \quad 0.022$

0.146

$0.728-0.164$

0.115

\begin{tabular}{ccccc} 
Random-effects Parameters & Estimate & Std. Err. & [95\% Conf. Interval] \\
\hline Identity & & & & \\
Var (Brand personality_X) & 0.013 & 0.012 & 0.002 & 0.076 \\
Var (_cons) & 0.040 & 0.024 & 0.012 & 0.130 \\
Var (Residual) & 0.390 & 0.032 & 0.332 & 0.459 \\
\hline
\end{tabular}

Source: Primary Data

As depicted in Table 5, the results of Restricted Maximum Likelihood Estimation (REML) of the hypothesized moderating effect of strategic marketing partnerships on the relationship between brand personality and customer service delivery of public universities indicate a random significant effect of strategic marketing partnerships between brand personality and customer service delivery with the model summary showing (chi-square= 218.20, p-value $=0.000$ ). The interaction effect of strategic marketing partnerships on brand personality and customer service delivery has a fixed significant effect $(\beta=0.084, Z=2.670$, $p$-value $=0.008)$. whilst, the strategic marketing partnerships was found to be significant at random intercept and the random slope. The random moderating effect of strategic marketing partnerships on the relationship between brand personality and customer service delivery between universities was significant ( $\mathrm{ICC}=9.3 \%, \mathrm{LR}=14.81$, p-value $=0.0006$ ).

In relation to the foregoing findings, the null hypothesis [ $\mathrm{H}_{02 \mathrm{a}}$ ] which states that "Strategic marketing partnerships does not significantly moderate the relationship between brand personality and customer service delivery of 
public universities in Kenya" would be rejected while the alternative hypothesis $\left[\mathrm{H}_{2 \mathrm{a}}\right]$ would be accepted.

\section{Summary of Findings}

The study identified that:

(i) Brand personality has a significant influence on customer service delivery of public universities in Kenya.

(ii) Strategic marketing partnerships significantly moderate the relationship between brand personality and customer service delivery of public universities in Kenya.

\section{Discussions}

On evaluating the contribution of this study to managerial practice, theory and policy, it can be argued that brand personality complimented by strategic marketing practice can influence customer service delivery in the university context positively. The model used in testing the effect of brand personality and strategic marketing partnerships on customer service delivery in the university context fits effectively in terms of explanatory power. The model provides support to the brand personality model and brand equity theory. The results of this study imply that despite direct path postulated by the brand personality model in the product sector, brand personality is equally directly linked to customer service delivery in the education service sector. These findings correspond with that of Ali and Marjan (2012, Nathan (2013), Agyapong (2011) and Mutinda (2016) who found out that brand personality had a significant influence of organizational performance in terms of service delivery. Synonymously, these findings are in line with that of Rutter (2013) who identified that marketing channels had a positive moderating relationship between brand personality and performance of higher institutions in the United Kingdom.

On the contrary, Bhakar et al. (2012) acknowledged that strategic marketing partnership had no influence on organizational performance. Mohamud et al. (2015) affirmed that strategic marketing partnerships had a significant impact on organizational performance though results may vary from one sector to another. However, the findings are incompatible to results by Banahene (2017); Thongthip and Polyorat (2015). Numerous studies have been conducting seeking to investigate the direct link between strategic marketing partnerships and organizational performance or brand performance (Fateh \& Boualem, 2014; Giovanni \& Daniela,2018 \& Matti et al. 2015). It can be observed from these studies that researchers have paid little attention on examining the moderating effect of strategic marketing partnerships on the relationship between brand personality and customer service delivery in the university context. Beyond the ordinary link of strategic marketing partnership 
and customer service delivery, this study depicts that strategic marketing partnerships partially moderates the relationship between brand personality and customer service delivery. Brand personality complimented with strategic marketing partnerships initiatives such as co-branding, co-research and codistribution strongly influence customer service delivery in the university context.

\section{Conclusion}

This study vividly demonstrates that brand personality can aid significantly in improving customer service delivery of public universities in Kenya. Service gaps experienced by customer of public universities could be a s result of failure of university managers to emphasize brand personality as marketing strategy of attracting and retaining customers. Further, strategic marketing partnerships was also found to have a significant indirectly effect on the relationship between brand personality and customer service delivery in the university context. Therefore, it is concluded that customer service delivery in the university context can positively complimented with strategic marketing partnerships if effectively embraced. Inability of university managers to recognize strategic marketing partnerships as a complement of customer service delivery in the university context can be one of the aspects that has contributed to dissatisfactory services provided in the university context.

\section{Recommendations}

Based on the results of this study, it is recommended that:

(i) For public universities in Kenya to attract and retain more students, university managers should prioritize on embracing brand personality practices such as brand sophistication, competence, sincerity, excitement and ruggedness.

(ii) For enhanced customer service delivery in the university context, university managers should complement brand personality with strategic marketing partnerships such as co-distribution, cobranding, co-research.

(iii) For global competitiveness of public universities in Kenya, university managers should recognize and emphasize on brand personality as well as strategic marketing partnerships for customer equity.

\section{Limitations}

Despite the fact that the objective sought by the study was achieved, empirical limitations attributed to the approach used were evident. However, future studies can overcome this limitation by adopting other approaches such 
as structural equation approach to examine whether there exists convergence of the results. Longitudinal research design is also recommended in future studies as it seeks to examine perception of brand personality over a long period of time within the university context. The skewed results of the study variables were associated with over-reliance of only one category of students in the university. Future studies should seek to use a wide scope of respondents by including first, second and third years to examine whether there exists collaboration of results. Future scholars should seek to conduct comparative studies between private and public universities to ascertain whether there exist differences of results.

\section{References:}

1. Aaker, D., \& Jennifer, L. (1997). Dimensions of Brand Personality. Journal of Marketing Research, 34 (3), 347-56.

2. Abdulsattar, A. A. (2019). Brand personality dimensions of Nike sportswear. Journal of Business and Retail Management Research (JBRMR), 13 (4), 1-11

3. Amel, R., Ayman, S., Mohamed, A. R., \& Alaa A. B. (2018). The Role of Branding on Educational Performance in the Egyptian Private Universities. Open Access Library Journal, 5 (1) 1-14.

4. Banahene, S. (2017). The Impact of Brand Personality and Students' Self-Concept on Brand Engagement. International Journal of Business and Social Research. 7 (12), 1-43

5. Berry, L. L. (1995). Relationship marketing of services: growing interest, emerging perspectives. Journal of the Academy of Marketing Science, 23 (4), 119- 236.

6. Bhakar, S. \&, Shailja, R. \& Shilpa, T. (2012). The Impact of CoBranding on Customer Evaluation of Brand Extensions. Prestige International Journal of Management and IT, 1 (3), 21-53.

7. Birori, O. W. (2014). Internal Customer Satisfaction Assessment in the Public Sector: A Case Study of Fleet Management Services Delivery. International Journal of Recent Research in Commerce Economics and Management, 1(2), 12-28.

8. Bijuna, C. Mohan \& A. H. Sequeira (2016). The Impact of Customerbased Brand Equity on the Operational Performance of FMCG Companies in India. IIMB Management Review 28, 13-19.

9. Banahene, S. (2017). The Impact of Brand Personality and Students' Self-Concept on Brand Engagement. International Journal of Business and Social Research. 7, (12), 176-189

10. Byrne, D. (2017). Data Analysis and Interpretation. Project Planner ( $7^{\text {th }}$ Ed.). [E-book]. Retrieved from http://books.google.co.nz 
11. Charraz, O., \& Muhammad, S., R. (2014). Investigation of the Relationship of Brand Personality, Subjective Norm and Perceived Control on Consumers' Purchase Intention of Organic Fast Food; Modern Applied Science, 8(3), 2014.

12. Chin-Tsu C. (2016). The Investigation on Brand Image of University Education and Students' Word-of-Mouth Behaviour. Canadian Center of Science and Education, 6 (4), 1-11.

13. Chinomona, C. Masinge, G. \& Sandada, M. (2014). The Influence of E-Service Quality on Customer Perceived Value, Customer Satisfaction and Loyalty in South Africa. Mediterranean Journal of Social Sciences, 5 (9), 1-23.

14. Commission for University Education (CUE). (2016, December 14). Annual Report. Retrieved from http://www.cue.or.ke.

15. Commission for University Education Report (CUE) (2018). List of Chartered Universities in Kenya. Retrieved from http://www.cue.or.ke.

16. Doyle, P. \& Stern P. (2010). Marketing Management and Strategy, $\left(4^{\text {th }}\right.$ Ed). London: Prentice Hall.

17. Eldegwy, A., Elsharnouby, T. H., \& Kortam, W. (2018) "How sociable is your university brand? An empirical investigation of university social augmenters' brand equity", International Journal of Educational Management, 32(5),912-930

18. Ewa, G. \& Wawrzyniec. R. (2019). City Brand Personality Projected by Municipalities from Central and Eastern Europe Countries-A Comparison of Facebook Usage. Sustainability, 11, 5440; doi:10.3390/su11195440

19. Fateh, S. \& Boualem, A. (2014). Do strategic partnerships create value? The empirical case of SBF 250 firms. $5^{\text {th }}$ International Research Meeting in Business Management (IRMBAM 2014)

20. Gary, D., José, I., R., M., Susan, W., Melisa, M. \& Theresa, L. (2018). Brand personality: Theory and Dimensionality. Journal of Product \& Brand Management, 27 (2), 115-127.

21. Giovanni, S. \& Daniela, C. (2018). Managing Strategic Partnerships with Universities in Innovation Ecosystems. University of Basilicata, Italy. Journal of Open Innovation, Technology, Market and Complexity, 4 (25), 1-13.

22. Habibollah, D. \& Zahra, A. (2013). The Moderating Effects of Product Involvement on Determinants of Brand Equity on Iranian Young Consumers' viewpoint. Technical Journal of Engineering and Applied Sciences Journal, 3 (22), 15-30.

23. Homburg, C., Kuester, S. \& Krohmer, H. (2009). Marketing Management, a contemporary perspective. London: McGraw Hill. 
24. Hsu, C. H. C. (2014). Brand Evaluation of Foreign versus Domestic Luxury Hotels by Chinese Travelers. Journal of China Tourism Research, 10(1), 35-50.

25. Isaid, E. N. \& Faisal M. N. (2015). Consumers’ Repurchase Intention Towards a Mobile Phone Brand in Qatar: An exploratory Study Utilizing Theory of Reasoned Action Framework. Global Business Review, 16 (4), 594-608.

26. Israel, G. D. (2009). Determining Sample Size, Institute of Food and Agricultural Sciences. Florida: University of Florida.

27. Jayasundara, C., Ngulube, P. \& Majanja, M. K. (2010). Using Focus Groups to Investigate Service Quality Determinants for Customer Satisfaction in Selected University Libraries in Sri Lanka. South African Journal of Libraries and Information Science, 76 (2), 118-127.

28. Kapferer, J. (2010). The New Strategic Brand Management: Creating and Sustaining Brand Equity Long Term, 4th Edition. London: Kogan Page.

29. Keller, K. L. (2010). Brand Equity Management in a Multichannel, Multimedia Retail Environment. Special Issue, Journal of Interactive Marketing, 24 (2), 58-70.

30. Khian, S. O., Bang, N., S. \& Faridah, S. A. (2017). Consumer-based Virtual Brand Personality (CBVBP), Customer Satisfaction and Brand Loyalty in the Online Banking Industry. International Journal of Bank Marketing, 35(3), 370-390.

31. Kotler, P. (2010). Marketing Management (12th Ed.). Upper Saddle River, NJ: Pearson Prentice Hall

32. Kulecho, M. M. \& Anyieni, A. G. (2018). Strategic Partnerships and Performance of Listed Commercial Banks in Kenya. International Journal of Contemporary Aspects in Strategic Management (IJCASM), 2 (1), 1-13.

33. Magutu, O.P., Mbeche, I. M., Bitange N.R., Onserio N, Nyaanga, R. O. \& Ogoro O. T. (2010). Quality management practices in Kenyan educational institutions: the case of the University of Nairobi. African Journal of Business \& Management (AJBUMA). Retrieved from http://www.ajbuma.or.ke/

34. Malechwanzi, J. M \& Mbeke, C. (2016). Policies of Access and the Quality of Higher Education in China and Kenya: A comparative Study. Cogent Education, 3 (1), 1-56.

35. Matata, M. \& Oduor, P. (2014). Effects of Strategic Alliances on Organizational Performance: Supermarkets and Their Alliances in Kenya. European Journal of Business and Management, 6 (34), 1-19

36. Matti, J., Kristian, M., Petri, P., Heiner, E. \& Hans, M. (2015). Strategic Marketing and Business Performance of Three European 
Engineering Countries. International Journal of Business Research, 3 (1), 13-27.

37. Matokho, K. M. \& Anyieni, A.G. (2018). Strategic Partnerships and Performance of Listed Commercial Banks in Kenya. International Journal of Contemporary Aspects in Strategic Management (IJCASM), 2 (1), 1-13

38. Mohamud, G. Y., Mohamud, A. S. \& Mohamed, B. H. (2015). The Relationship between Strategic Management and Organizational Performance in Mogadishu-Somalia. European Journal of Research and Reflection in Management Sciences, 3(2), 42-51.

39. Mutinda, J. (2016). The Influence of Brand Personality on Customer Purchase Decision of Smartphone in Selected Public University Campuses in Nairobi CBD, Kenya. Published PhD Thesis. Kenyatta University. Kenyatta University. Retrieved from Ir-library.ku.ac.ke.

40. Nashwan, M. A. S. (2015). How does Marketing Strategy Influence Firm Performance? Implementation of Marketing Strategy for Firm Success. International Journal of Innovation and Economic Development, 1(3), 7-15.

41. Owino, O. E. (2013). The Influence of Service Quality and Corporate Image on Customer Satisfaction among University Students in Kenya. Published PhD Thesis. University of Nairobi. Retrieved from http://www.google scholar.

42. Parasuraman, A., Zeithaml, V. A. \& Berry, L. L. (1985). A conceptual model of service quality and its implications for future research. Journal of Marketing, 49 (4), 41-50.

43. Raghavan, S. \& Ganesh R. (2015). Addressing Service Quality to Increase Students' Satisfaction and Retention in Malaysian Private Higher Education Institutions. American Journal of Economics, 05, 243-250

44. Richard, R., Fiona, L. \& John, N. (2017). Brand personality in higher education: anthropomorphized university marketing communications. Journal of Marketing for Higher Education, 27 (1), 19-39

45. Rutter, N.R. (2013). Personality and Consistency between Marketing Channels on Performance within the UK Higher Education Sector. PhD Thesis. University of Easy Anglia, United Kingdom.

46. Sanjay, S. S. (2015). Service Quality, Student Satisfaction and Brand Equity: A Case Study of Select South African Universities. Doctoral Thesis. University of Cape Town

47. Sohini, N., Rejoice, T. M. \& Norman C. \& Eugine, T. M. (2019). The impact of corporate rebranding on brand equity and firm performance. Journal of Business and Retail Management Research (JBRMR), 13 (4), 2-11 
48. Soni, S.S. (2015). Service Quality, Student Satisfaction and Brand Equity: A Case Study of Select South African Universities. PhD Thesis. KwaZulu-Natal University. Retrieved on July, 2019.

49. Sun, X., Wnag, P., Lepp, A. \& Robertson, L. (2014). Symbolic Consumption and Brand Choice: Chinas Youth Hostels for the International Travel Market. Journal of China Tourism Research, 10(1), 51-68.

50. Teimouri, H., Fanae, N, Jenab, K. Khoury, S. \& Moslehpour, S. (2016). Relationship between Brand Personality and Customer Loyalty: A Case Study of Samsung Mobile Phone. International Journal of Business and Management,11 (2), 1-16

51. Thongthip, W. \& Polyorat, K. (2015). The influence of brand personality dimensions on perceived service quality and perceived service value. International Academic Conference in Paris (IACP), 1011th August 2015, Paris, France

52. UNESCO (2014). Higher Education in Asia: Expanding out, Expanding up - The Rise of Graduate Education and University Research. Montreal, Canada: UNESCO. 